\title{
STUDIES ON THE EFFECT OF DRAIN EFFLUENTS ON THE WATER QUALITY OF LAKE MANZALA, EGYPT.
}

\author{
Abdel -Samei A. Elewa', Ebtisam A. Saad ${ }^{2}$, \\ Mohamed B. Shehata ${ }^{1}$ and Mohamed H. Ghallab ${ }^{1}$
}

1. National Institute of Oceanography and Fisheries, Inland Water Branch. 2. Chemistry Department, Faculty of Science, Ain Shams University, Cairo, Egypt.

Keywords: Water quality, trace metals, agricultural wastes, Lake Manzala, drain effluents.

\section{ABSTRACT}

$\mathrm{T}$ he water quality of Lake Manzala was studied seasonally' during the period from autumn 2000 to summer 2001 . The results of physical parameters revealed that the values of transparency at the southern region are relatively low and reflect the type of effluents, characterized by high amounts of floating materials, which decrease the water transparency. Moreover, the electrical conductivity at these stations were somewhat high as a result of sewage and industrial wastes at that region. On the other hand, the chemical analysis of water showed high values of chemical oxygen demand (COD) and biological oxygen demand (BOD) but low levels of dissolved oxygen (DO) especially at the southern region opposite to Hadous and Bahr El-Baqar drains, in addition to high levels of trace metals.

\section{INTRODUCTION}

Lake Manzala lies at the south-eastern Mediterranean coastal region between Damietta branch to the west and Suez Canal to the east (long $31^{\circ} 4 \grave{5}, 3215 \mathrm{E}$ lat $31^{\circ} 00^{\circ}, 31^{\circ} 00^{\prime}, 31^{\circ} 35 \mathrm{~N}$ ). About 7500 million $\mathrm{m}^{3}$ of untreated waste water are currently coming from five governorates namely: Port Said, Ismaliya, Dakhliyia, Sharkiya and Damietta, besides seven drains (Abdel-Baky et al. 1998; Samir 2000).

Lake Manzala is the most important among all Egyptian Lakes, since it produces about $10 \%$ of the total fish yield in Egypt (Mohamed, 2001). El-Enany (2004) studied the ecological and biological characteristics of Lake Manzala with special reference to its water quality 
and sediment productivity. He reported that the lake is subjected to continuous steady flow of pollutants through numerous drains that discharge heavy load of organic and inorganic pollutants.

Shakweer (2005) studied the chemistry of Lake Manzala and pointed out that most of chemical parameters are relatively high at the southern areas of the lake, near to the outlets of Bahr El-Baqar and Hadous drains.

Over the last few decades, the lake has undergone dramatic environmental changes (Zyadah, 1995; Shakweer, 2005). Therefore, the present study aimed to give an over view about the impacts of the southern drains effluents on the water quality condition of Lake Manzala.

\section{MATERIALS AND METHODS}

The water quality of Lake Manzala was studied during four successive seasons (from autumn 2000 to summer 2001). Eight stations were selected to cover the different regions of the investigation area (Fig. 1), which can be described in the following table.

\begin{tabular}{|c|l|l|}
\hline No. & \multicolumn{1}{|c|}{ Station } & \multicolumn{1}{|c|}{ Location at the lake } \\
\hline 1 & El-Zarka & At the north western part of the lake \\
2 & Bahr El-Baqar & At the outlet of Bahr El-Baqar drain \\
3 & Hadous - Ramsis outlet & At the outlet of Ramsis and Hadous drain \\
4 & Bahr El-Bashtier & At the outlet of New Bahr El-Baqar drain \\
5 & Bahr El-Genka & At the middle part of the lake \\
6 & Bahr Legan & At the middle part of the lake \\
7 & El-Materiya & At the middle-eastern part of the lake \\
8 & Bahr El-Gamil & At the north-eastern part of the lake \\
\hline
\end{tabular}

Water samples were collected from sub-surface layer (average lake depth is about $140 \mathrm{~cm}$ ) by using polyvinyl chloride Van Dorm bottle (1.5 Liter capacity).The water samples were kept in a well stoppered polyethylene plastic bottles until arrival to the laboratory. Temperature and transparency were determined at the field then analyses. were undertaken for other physical and chemical parameters according to the standard methods described in APHA (1995).

For trace metals, the samples were acidified with conc. nitric acid (to a $\mathrm{pH}<2$ ) and digested by nitric-perchloric acid mixture. The total 
metal concentrations were determined by Atomic Absorption Spectrophetometer (Model Hitachi 170-30) with a graphite atomizer (GAZ).

\section{RESULTS AND DISCUSSION}

\section{Water temperature}

Temperature is one of the most important parameters of water quality (EPA, 1976). Due to the shallowness of the lake and the effect of wind action, there was no sharp differences in the temperature at most stations $\left(16-27^{\circ} \mathrm{C}\right)$ and $\left(20-30^{\circ} \mathrm{C}\right)$ during cold seasons (autumn \& winter) and hot seasons (spring $\&$ summer) respectively, and the increase or decrease in water temperature may be explained on the basis of climatic effects during the year round.

\section{Transparency}

The transparency values were very low at all stations (Table 1), except stations $I$ and 8 , since both contain less amounts of sewage and industrial wastes, while other stations are strongly affected with drain effluents at the southern region of the Lake.

Electrical Conductivity (EC)

The variations in water conductivity were relatively limited (Table 1), and characteristic for brackish water at most stations, except station 8, which has high EC value, that is related to the Sea-Lake connection through El-Gamil outlet (El-Enany, 2004). pH

The $\mathrm{pH}$ value is a very important factor in the study of water chemistry (APHA 1995). The present work showed that most of the $\mathrm{pH}$ values at the lake are at the alkaline side (Table 1). The high recorded values during spring may be attributed to photosynthesis activity, which agrees with Ueda et al. (2000), while the lower in $\mathrm{pH}$ values recorded during summer could be explained on the basis of organic matter decomposition, which agrees with Fishar (1999).

Dissolved Oxygen (DO)

The values of DO fluctuated between $3.0-8.4 \mathrm{mg} / \mathrm{l}$ with limited seasonal and regional variation. The highest values were recorded during the cold period (autumn and winter), while the lowest values were observed during the hot period (spring and summer) as a result of temperature elevation (Cole, 1979; APHA, 1995). Generally, the values of DO at most stations were relatively low except stations 1 and 8, where 
both are far from the effect of drain effluents, which strongly affected the south-eastern region (stations $2-7$ ). This is supported by the high values of $C O D$ at these stations during the year round (Table 3 ), which agreed with that obtained by Zyadah (1995).

Biological Oxygen Demand (BOD)

BOD measures the dissolved oxygen consumed by microorganisms present in the studied samples to stabilize any biodegradable organic matter, as well as the quantity of oxygen used in its respiration (APHA, 1995). The BOD values varied between 3.6-9.0 $\mathrm{mg} / \mathrm{l}$ (Table 3 ). The high BOD values recorded during autumn may be attributed to photosynthesis activity at the surface water and high original DO. This agrees with Ghallab (2000) at Delta Barrage region and Abdo (2002) at Rosetta branch, while the low BOD recorded during winter could be explained on the basis of low activity of microorganisms, as a result of low temperature, which agrees with the data obtained by Zyadah (1995).

\section{Chemical Oxygen Demand (COD)}

COD is the total amount of $\mathrm{O}_{2}$ required to oxidize all organic matter and oxidizable compounds present in the water sample into $\mathrm{CO}_{2}$ and $\mathrm{H}_{2} \mathrm{O}$ (APHA, 1995).The values of $\mathrm{COD}$ varied between $5.0-19.4$ $\mathrm{mg} / \mathrm{l}$ (Table 3); the high recorded COD values during summer may be due to the high decomposition rate of organic matter as a result of low DO content, which agreed with the results of Zyadah (1995). The low recorded COD values during spring could be attributed to phytoplankton abundance (Visser, 1970; Fishar, 1999).

\section{Heavy Metals}

Trace metals play an important role in the geochemical and biological cycle of aquatic environment (Purves, 1988). They have a great ecological significance due to their toxicity and accumulation behaviour and aren't biodegradable and undergo a global ecobiological cycle, in which natural water is the main pathway (Purves, 1988; Pardo et al., 1990). The present study showed that iron levels varied from $0.09-6.04$ $\mathrm{mg} / \mathrm{l}$ and the highest value was observed at the southern regions (stations $2-5$ ) in front of Bahr El-Baqar and Hadous outlets (Table 4).

A similar trend was observed with other trace metals. For example; Mn (0.024 - $0.395 \mathrm{mg} / \mathrm{l})$ showed high concentrations during hot seasons due to releasing of $\mathrm{Mn}$ from sediment under low DO content as mentioned by Yacaub (1999), while the low levels were recorded during cold seasons, due to the oxidation and precipitation on the bottom 
sediment as mentioned by Cole (1979). Moreover, the high concentration of $\mathrm{Mn}$ recorded at stations ( $3-6)$, as shown in Table (4), could be attributed to domestic wastes discharged from Bahr El-Baqar and Hadous drains, which agreed with Shakweer (2005).

The correlation matrix of $\mathrm{Mn}$ showed a negative correlation with $\mathrm{pH}$ and $\mathrm{DO}(\mathrm{r}=-0.56$ and -0.8 respectively), which reveals that $\mathrm{Mn}$ precipitates in oxidizing form at high $\mathrm{pH}$ values.

For $\mathrm{Cu}$, its concentration varied from $0.004-0.28 \mathrm{mg} / \mathrm{l}$. The decrease in $\mathrm{Cu}$ concentration during cold period may be due to formation of $\mathrm{CuO}$, that rapidly changed to $\mathrm{Cu}(\mathrm{OH})_{2}$ and precipitates at the bottom sediment, which agreed with Masoud et al. (1994). The correlation matrix of copper showed a negative correlation with temperature and DO $(r=-0.56$ and -0.33 respectively), which means that copper may precipitate in oxidized form at high temperature.

Zinc concentration fluctuated between $0.007-0.057 \mathrm{mg} / 1$, and the high $\mathrm{Zn}$ concentration was observed during the cold period, which could be attributed to the decrease in sorption of zinc at organic matter with drops with temperature. This agrees with that reported by Wamer aind Zimmerman (1994). The decrease in $\mathrm{Zn}$ concentration at stations $(1,6,8)$ during spring may be due to the reaction of $\mathrm{Zn}$ with high concentration of $\mathrm{H}_{2} \mathrm{~S}$ to from insoluble $\mathrm{ZnS}$ under anoxic condition, as reported by Birch et al. (1996).

$\mathrm{Zn}$ showed a positive correlation with $\mathrm{BOD}$ and $\mathrm{COD}(\mathrm{r}=0.79$ and 0.81 respectively) which explains that most of zinc compounds are biologically and chemically degradable, while a negative correlation was observed with DO $(r=-0.78)$.

For cadmium, its concentration varied between $0.010-0.034$ $\mathrm{mg} / \mathrm{h}$, and the high concentrations were recorded during the cold period, which could be explained on the basis of mobilizing of cadmium from sediment under low temperature (El-Shebly, 1996).

For lead, its concentration fluctuated from $0.020-0.057 \mathrm{mg} / \mathrm{l}$ and the low concentrations were recorded during cold period, which may be attributed to its precipitation in the form of sulphide and carbonate, which agreed with that reported by Zyadah (1995).

It can be concluded that the southern drains play an important role in causing a severe pollution in Lake Manzala, especially at the southeastern regions which receive a great quantities of effluents from Bahr ElBaqar, Hadous and Ramsis drains. These severe polluted effluents reflect 
the high levels of most chemical parameters. The studied heavy metals showed that $\mathrm{Fe}, \mathrm{Cd}$ and $\mathrm{Pb}$ concentrations exceed the maximum permissible limits according to the Egyptian Chemical Standards (ECS) (1994), while other elements concentrations exceed the maximum permissible limits according to other international criteria (Table 5).

\section{REFERENCES}

Abdo, M. H. (2002). Environmental studies on Rosetta branch and some chemical applications at the area extends from El-Kanater El-Khyria to Kafr-El-Zyat city. Ph. D Thesis, Fac. Sci., Ain Shams Univ., Cairo, Egypt.

APHA, (1995) American Public Health Association: Standard methods of the examination of water and waste water. New York,1193 pp.

Birch, L.; Hanselman, K. W. and Bachofen, R. (1996). Heavy metal conservation in Lake Cadagne sediments; Historical records of thropagenic emissions in a Meromictic Alpine Lake Wat. Res., 30: $679-687$.

Cole, G. A. (1979). Textbook of Limnology, $2^{\text {nd }}$ ed., C. V. Mosby company. Toronto, London. $401 \mathrm{pp}$.

El-Enany, H. R. (2004). Ecological and biological studies on Lake Manzalah with special reference to their water quality and sediment productivity. M. Sc.Thesis, Fac. Sci., Al-Azhar Univ., $386 \mathrm{pp}$.

El-Shebly, A. A. (1996). Effect of drainage water on fish farms at Lake Manzalah, Egypt. Ph. D. Thesis, Fac. Sci, Mansoura, Univ., Egypt.

EPA, (1976): U. S. Environmental protection Agency (EPA) Quality - criteria for water, Washington, $256 \mathrm{pp}$. 
Fishar, M. R. A. (1999). Distribution and abundance of benthic assemblages in El-Gamil basin (Lake Manzala) A-Meiobenthos, Bull. Nat. Int. Oceanogr. Fish, A. R. E, 25: 151- 165.

Ghallab, M. H. M. (2000). Some physical and chemical changes on River Nile down stream of Delta Barrage at El-Rahawy Drain. M. Sc. Thesis, Fac. Sci., Ain Shams Univ., Cairo, Egypt.

Massoud, M. S.; Elewa, A. A. and Awad, F. K. (1994). Distribution of some trace metals in River Nile water, Bull. Fac. Sci., Assiut Univ., 23: $67-82$.

Mohamed, F. A. (2001). Impacts of environmental pollution in the southern region of Lake Manzala, Egypt, on the histological structures of the Liver and Intestine of Oreochromis niloticus and Tilapia zillii, J. Egypt. Acd. Soc. Environ. Develop., 2(2): $25-42$.

Purvas, D. (1988). Trace element contamination of the environmental ElSevier, Amsterdam.

Samir, A. M. (2000). The response of benthic foraminifera and ostracods to variations of pollution sources: A study from two lagoon in Egypt. J. Foraminifera Research, 30(2): 83-98.

Shakweer, L. M. (2005). Ecological and fisheries development of Lake Manzalah (Egypt) 1- Hydrography and chemistry of Lake Manzalah. Egypt. Aqu. Res.,31(1):

Visser, S. A. (1970). A review of the distribution of organic compounds in fresh water Lakes and Rivers. The African Journal of Tropical hydrobiology and Fisheries.

Wamer, L. A. and Zimmerman, A. P. (1994). The influence of temperature and sodium chloride on cadmium, copper and zinc 
partitioning among suspended particulate and dissolved phases in an urban river. Wat. Res., 28(9): 1921 - 1931.

Yacoub, A. M. (1999). Effect of pollution in different localities of River Nile on Clarias lazera (cev.) Ph. D. Thesis, Fac. Sci., Ain Shams Univ.

Zyadah, M. A. (1995). Environmental impact assessment of pollution in Lake Manzalah and its effect on fish Ph. D. Thesis, Fac. Sci., El-Mansoura Univ., 127 pp.

Zyadah, H. A. (1998). Heavy metals concentrations in some organs of Oreochromis (Tilapia) aureus Stein in Lake Manzalah, Egypt J. Egypt. Ger. Soc. Zool., 25: 237-256. 


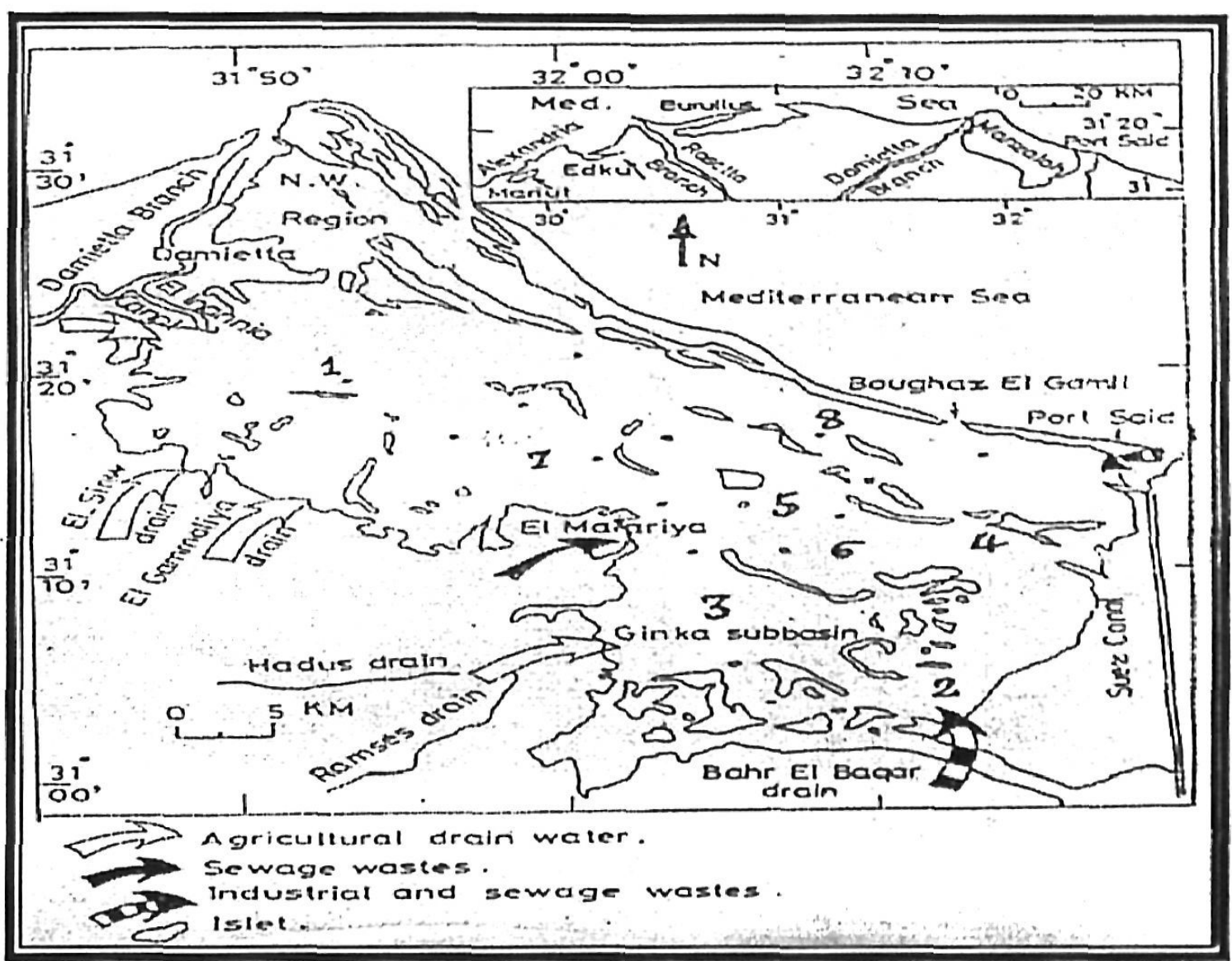

Fig. (1): Diagrammatic map for Lake Manzala showing the water sampling stations 


\begin{tabular}{|c|c|c|c|c|c|c|c|c|c|}
\hline$\infty$ & $\nu$ & $a$ & en & $\leftarrow$ & $\omega$ & No & - & & ? \\
\hline : & $\vec{U}$ & U & $\tilde{A}$ & $\tilde{s}$ & 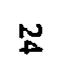 & 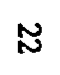 & $\underline{N}$ & $\vec{g}$ & \multirow{3}{*}{ 超 } \\
\hline \begin{tabular}{l}
\multirow{\infty}{\infty}{} \\
8 \\
8
\end{tabular} & 㞻 & 怘 & $\frac{\omega}{8}$ & $\stackrel{\sim}{\dddot{O}}$ & 号 & $\stackrel{\breve{\Xi}}{8}$ & 怘 & 国 & \\
\hline$u$ & 品 & $\overrightarrow{0}$ & $\underset{\sim}{*}$ & 苂 & $\underline{\omega}$ & $\stackrel{\sim}{0}$ & ha & 式 & \\
\hline$\vec{\infty}$ & $\Xi$ & $\Xi$ & $\vec{a}$ & $\bar{a}$ & $\bar{a}$ & $\Xi$ & $\bar{\infty}$ & 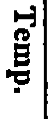 & \multirow{3}{*}{ 超 } \\
\hline $\begin{array}{l}\bar{\sigma} \\
\ddot{厶}\end{array}$ & 茖 & $\stackrel{\sim}{\circ}$ & $\begin{array}{l}\stackrel{\leftrightarrow}{8} \\
\mathbb{8}\end{array}$ & $\stackrel{\text { 感 }}{\circ}$ & $\underset{\sim}{\stackrel{\sim}{W}}$ & $\begin{array}{l}\text { 志 } \\
\text { 出 }\end{array}$ & $\underset{\tilde{U}}{\tilde{U}}$ & 田 & \\
\hline$\vec{\omega}$ & $\underset{\sim}{W}$ & 岩 & $\ddot{\circ}$ & $\tilde{\omega}$ & $\ddot{\sigma}$ & 出 & $g$ & $\begin{array}{l}3 \\
7 \\
0 \\
0\end{array}$ & \\
\hline$\tilde{\omega}$ & $\simeq$ & $\tilde{\sigma}$ & $\underline{\sim}$ & 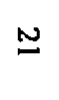 & 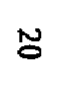 & $\tilde{\sigma}$ & $\cong$ & 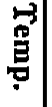 & \multirow{3}{*}{ 营. } \\
\hline $\begin{array}{l}\overrightarrow{0} \\
\text { ర0 }\end{array}$ & $\tilde{\hat{E}}$ & 岕 & 总 & 忍 & $\stackrel{+}{\stackrel{+}{\circ}}$ & 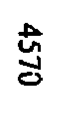 & 岕 & 명 & \\
\hline 능 & 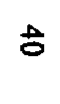 & $\tilde{N}$ & 茨 & $\widetilde{\sigma}$ & 尺 & $\bar{n}$ & $\approx$ & 氞 & \\
\hline$\stackrel{\infty}{\infty}$ & $\tilde{\infty}$ & $\underset{\infty}{N}$ & $\mathcal{J}$ & $\mathfrak{N}$ & $\stackrel{w}{\circ}$ & $\stackrel{N}{\infty}$ & $\tilde{w}$ & $\begin{array}{l}0-3 \\
0 \\
0\end{array}$ & \multirow{3}{*}{ 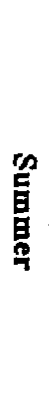 } \\
\hline $\begin{array}{l}\omega \\
\stackrel{\omega}{\mathbf{s}}\end{array}$ & 岕 & $\overrightarrow{\mathrm{S}}$ & $\begin{array}{l}\text { 峁 } \\
\text { t }\end{array}$ & $\stackrel{\text { 音 }}{\mathrm{g}}$ & 空 & $\underset{8}{\sigma}$ & ్ㅗㅇ & 包 & \\
\hline$\vec{\partial}$ & 岩 & 岁 & $\ddot{\sigma}$ & 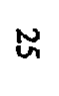 & $\tilde{N}$ & $\tilde{O}$ & 용 & $\begin{array}{l}7 \\
7 \\
0\end{array}$ & \\
\hline
\end{tabular}



QUALITY OF LAKE MĀNZALA

Table (2): Seasonal variations of $\mathrm{pH}$ and $\mathrm{DO}$ concentrations (mg/l) in Lake Manzala water during 2000 - 2001.

\begin{tabular}{|c|c|c|c|c|c|c|c|c|}
\hline \multirow{2}{*}{ Station } & \multicolumn{2}{|c|}{ Autumn } & \multicolumn{2}{c|}{ Winter } & \multicolumn{2}{c|}{ Spring } & \multicolumn{2}{c|}{ Summer } \\
\cline { 2 - 9 } & $\mathbf{D O}$ & $\mathbf{p H}$ & $\mathbf{D O}$ & $\mathbf{p H}$ & $\mathbf{D O}$ & $\mathbf{p H}$ & $\mathbf{D O}$ & $\mathbf{p H}$ \\
\hline $\mathbf{1}$ & 7.80 & 8.22 & 10.00 & 7.50 & 7.60 & 8.31 & 5.00 & 8.64 \\
\hline $\mathbf{2}$ & 4.20 & 7.44 & 5.00 & 7.47 & 4.60 & 7.60 & 3.20 & 7.35 \\
\hline $\mathbf{3}$ & 3.60 & 7.78 & 4.40 & 7.56 & 4.00 & 7.39 & 3.00 & 7.29 \\
\hline $\mathbf{4}$ & 4.40 & 7.91 & 5.20 & 8.09 & 4.80 & 7.43 & 3.40 & 7.18 \\
\hline $\mathbf{5}$ & 4.20 & 7.31 & 4.80 & 7.41 & 3.80 & 7.54 & 3.00 & 7.58 \\
\hline $\mathbf{6}$ & 3.80 & 8.10 & 5.20 & 7.68 & 4.40 & 7.33 & 3.60 & 7.53 \\
\hline $\mathbf{7}$ & 4.40 & 7.21 & 5.00 & 7.82 & 4.20 & 7.37 & 4.00 & 7.39 \\
\hline $\mathbf{8}$ & 8.40 & 8.20 & 8.20 & 7.68 & 6.80 & 8.30 & 5.80 & 7.81 \\
\hline
\end{tabular}

Table (3): Seasonal variations of $B O D$ and $C O D$ concentrations ( $\mathrm{mg} / \mathrm{l}$ ) in Lake Manzala water during 2000 - 2001.

\begin{tabular}{|c|c|c|c|c|c|c|c|c|}
\hline \multirow{2}{*}{ Station } & \multicolumn{2}{|c|}{ Autumn } & \multicolumn{2}{c|}{ Winter } & \multicolumn{2}{c|}{ Spring } & \multicolumn{2}{c|}{ Summer } \\
\cline { 2 - 9 } & BOD & COD & BOD & COD & BOD & COD & BOD & COD \\
\hline 1 & 5.00 & 7.60 & 4.00 & 7.00 & 2.60 & 6.40 & 5.40 & 8.00 \\
\hline 2 & 8.20 & 14.20 & 5.80 & 10.20 & 4.00 & 9.00 & 6.20 & 13.40 \\
\hline 3 & 6.80 & 12.60 & 4.60 & 8.80 & 3.60 & 10.40 & 5.60 & 11.80 \\
\hline 4 & 9.00 & 14.00 & 7.00 & 15.20 & 6.40 & 16.80 & 8.40 & 19.40 \\
\hline 5 & 6.40 & 12.80 & 4.00 & 7.40 & 3.00 & 9.60 & 7.20 & 14.60 \\
\hline 6 & 6.00 & 10.40 & 4.80 & 10.60 & 5.20 & 8.00 & 7.00 & 13.80 \\
\hline 7 & 5.80 & 12.00 & 3.60 & 9.20 & 4.00 & 7.40 & 6.00 & 10.00 \\
\hline 8 & 3.60 & 6.20 & 3.00 & 6.80 & 2.80 & 5.00 & 4.20 & 8.40 \\
\hline
\end{tabular}




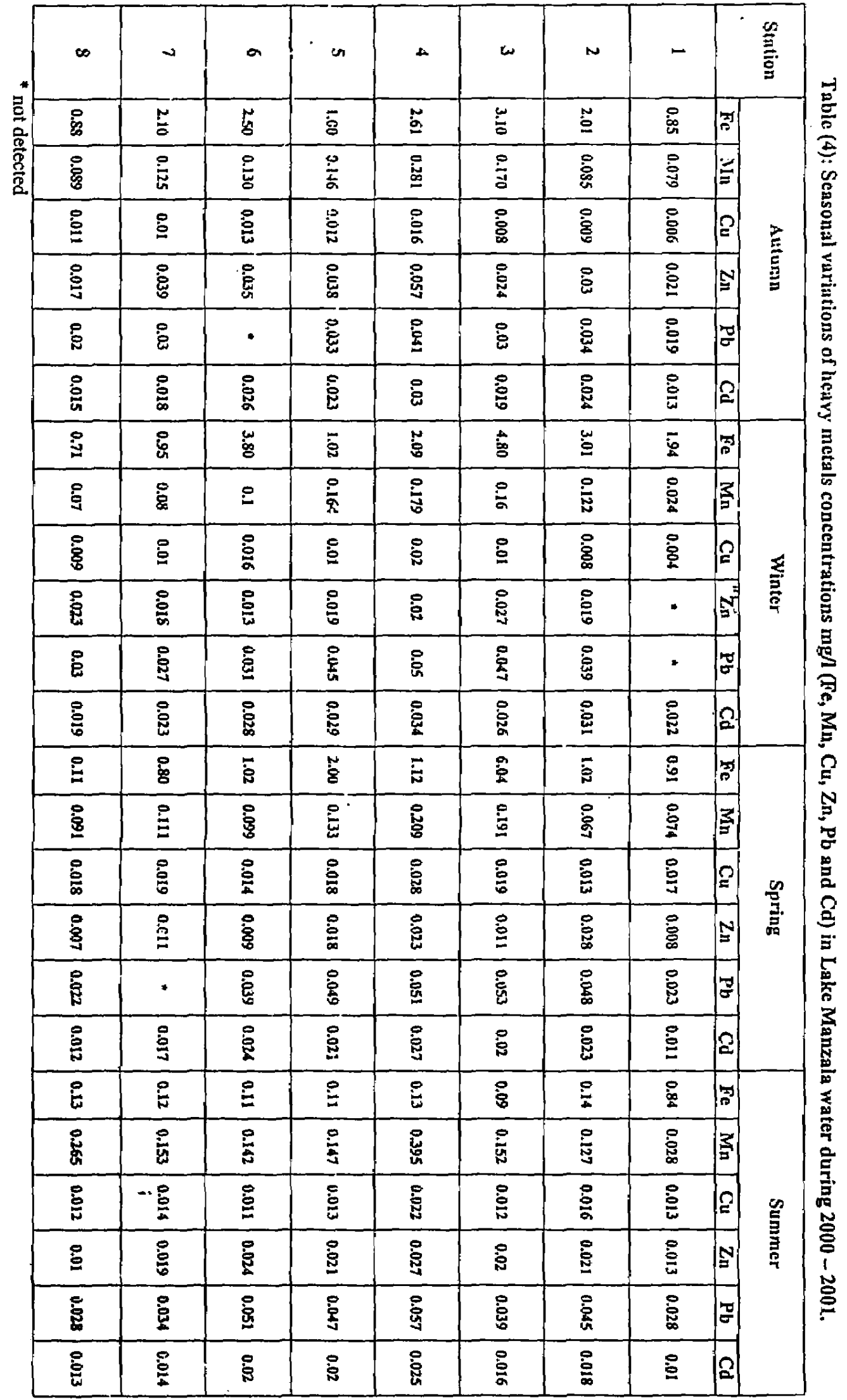


Table (5): Standard limits (maximum permissible limits) of drinking water parameters according to different criteria.

\begin{tabular}{|c|c|c|c|c|c|c|}
\hline Parameters & Units & $\begin{array}{c}\text { WHO } \\
\text { Standards }\end{array}$ & $\begin{array}{c}\text { USEPA } \\
\text { Standards }\end{array}$ & $\begin{array}{c}\text { ESS } \\
\text { Standards }\end{array}$ & $\begin{array}{c}\text { ECS } \\
\text { Standards }\end{array}$ & $\begin{array}{c}\text { Present } \\
\text { study }\end{array}$ \\
\hline $\mathrm{pH}$ & & $6.5-8.5$ & $6.5-8.5$ & $6.5-8.5$ & $6.0-9.0$ & $6.88-8 . \hat{1} 1$ \\
\hline Temperature & ${ }^{\circ} \mathrm{C}$ & - & - & - & 35 & $16-30$ \\
\hline Color & & NO & NO & NO & $\mathrm{NO}$ & NO \\
\hline BOD & $\mathrm{mg} / \mathrm{l}$ & - & - & - & 20 & $2.6-9.0$ \\
\hline COD & $\mathrm{mg} / \mathrm{l}$ & - & - & - & 30 & $5.0-19.4$ \\
\hline $\mathrm{Fe}$ & $\mathrm{mg} / \mathrm{l}$ & 0.3 & 0.3 & 0.3 & 1 & $0.09-6.04$ \\
\hline $\mathrm{Mn}$ & $\mathrm{mg} / \mathrm{l}$ & 0.05 & 0.05 & 0.05 & 0.5 & $\begin{array}{c}0.024- \\
0.411\end{array}$ \\
\hline $\mathrm{Cu}$ & $\mathrm{mg} / 1$ & 1 & 1 & 0.1 & 1 & $\begin{array}{c}0.003- \\
0.055\end{array}$ \\
\hline $\mathrm{Zn}$ & $\mathrm{mg} / \mathrm{l}$ & 5 & 5 & 0.1 & 5 & $\begin{array}{c}0.007- \\
0.057\end{array}$ \\
\hline $\mathrm{Cd}$ & $\mathrm{mg} / 1$ & 0.005 & 0.01 & 0.005 & 0.01 & $\begin{array}{l}0.007- \\
0.9215\end{array}$ \\
\hline $\mathrm{Pb}$ & $\mathrm{mg} / \mathrm{l}$ & 0.05 & 0.005 & 0.05 & 0.05 & $\begin{array}{c}0.013- \\
0.062\end{array}$ \\
\hline
\end{tabular}

WHO, (1993) World Health Organization

USEPA, (2001) United States Environmental Protection Analysis

ESS, (1997) European Economic Community Standards

ECS, (1994) Egyptian Chemical Standards 